$\mathrm{XVI}-2 \cdot 3$ 最近の成型 . 造粒機*

歌 門 章 二**

新しい技術が開発されたり既存の技術に改良が加えら れると，その多くは，特許出願という形であらわれるの が最近の通例となっている。したがって，特許面からみ れば大体の実状および推移は察知できると思われるの で，本項では主としてこの面から最近の粉粒体の成型な らびに造粒機に関する技術をとりあげてみたい。

さて，近年粉粒体の消費量が増し各種工業中の造粒工 程の比重が高まるにつれ，ほとんど付随的な分野を占め ていたにすぎなかったこの種技術の 重要性が再認識さ れ，この「造粒」とい5操作が単位操作の一分野として 注目されるようになってきた。しかしながら，特許面て は，出願件数の增加こそあれ，画期的なるのや化学工学 的に興味のあるものはそれ汪と見当らない。そして，医 薬，肥料，合成樹脂工業などの各工業分野において，それ ぞれ独自の技術として出願, 登録されているものが多い。

以下これらの技術についてここ数年間に公告された公 報の中からその一端を紹介したいと思う。

\section{1． 压縮成型形成型・造粒機}

粉粒体の一定量を一定の大きさの型に供給し，压力を 加えて成型または造粒するるの，すなわち打錠機とか口 一ルブレスなどがあり，医薬品の分野で広く採用されて いるほか, 触媒, 飼料, 食品, 然料, 粉末冶金, 合成樹 脂などにも応用されている。

1）压緗打鎵機

これには，秤量と压縮と 1 力所で上杵，下杵扰よびフ ィーダーの移動で行な5単発式のすのと，この過程を円 板上に放射状に並んだ帠を回転させて行な5ロータリー 式のもの々がある。

単発式のものは, 実用新案関係のものが最近は若干認 められるにすきず，興味あるものは少ない。2，3 紹介 すると，台板上に棆状囲壁と中央に引火線導入漊のある 截頭円錐状突起または台を設け，この突起または台と囲 壁とでつくる型穴に粉末を供給し上杵を下げ成型する引 火線つき熱量計用試料錚剂の成型機1,2) とか，上杵に発 条を設け常に密度の均一な錠片をうることができるも の3，下杵ホルダーの防鷹装置に関するもの”などがあ る。

\footnotetext{
* 昭和 39 年 5 月 20 日受理

**特许宁霠㚗第 3 部
}

公告されている中には口ータリ一式の改良されたもの が多い。たとえば，環銫片の成型機において，成型金具 である下部金具に自転運動を与え，回転ホルダーの日内 で粉末のためきしみができ上下運動が不十分になる欠点 を改善したもの とか，図1に示すフメリカストークス 社の装置が提案されている6)。因は部分困で，これは横 断面がU字型の無床式給送脚部（48）をホッパー（34） に連接して設けた給送装置をるち，さらに，この粉末給 送装置の壁部を振動する振動装置 $(40 ， 53)$ を設けたも ので，非円滑流動粉末を用いる場合にも使用でき高速度 で打錠できるというものである。同様な材料供給装置に 関するるのとして（図 2，3参照），二つの水平に回転す る翼車 $\left(3^{\prime}, 4^{\prime}\right)$ をそなえ，この翼が，一方の翼が他方の 翼と係合し，そして回転方向に対し斜めに配置されたも
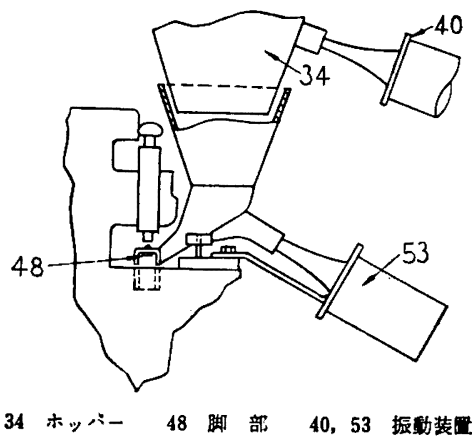

因 1

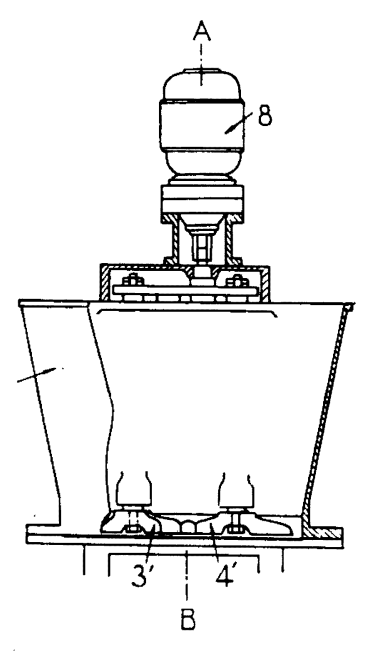

图 2 (図中番号は图 3 照) 


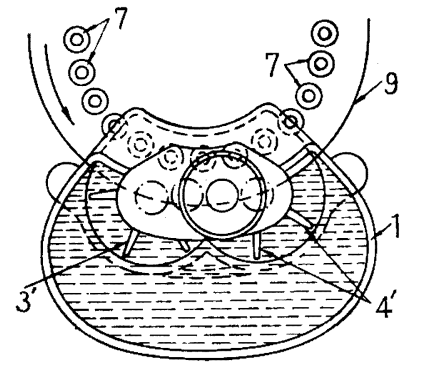

1. ホッペー 7. 型 $3^{\prime}, 4^{\prime}$ 摚样板基

困 3
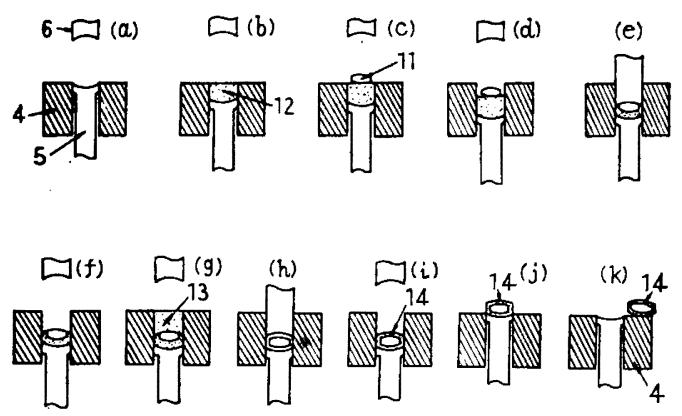

4. 日 5. 下杵 6 . 上杵 11 . 芯錠

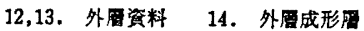

图 4

のが最近公告されている7゙。

なお，医薬品工業では，芯錠をある量の粉で包む被覆 錠㶡の製造技術がある。これは図4 亿示すような順序で 作動を行なわせるるので 2 重打錠機と称するものであ る8。

これも単発式だけでなく，ロータリー式のような量産 方式を採用することができる9 。

また， 2 層以上の層よりなる錠剤の製造装置として， 個々の層を形成する物質を順次母型に装入し，かつその 都度, すしくはすでに母型内にある層と一緒に準備圧搾 し，ついで最後の層のために必要な物質の装入後に一つ の錠剤全体の最終的な仕上压控を行な5ものがある。そ してこの際，機峨調整のためあるいは製品検査のため未 完成の錠肪をいつでもとり出せるように，回転テーブル の円周に分散されている母型内への材料の供給を中断で きるように工夫したものが昭和 37 年に公告されてい $3^{10)}$ 。

\section{2）その他の圧縮成型形成型・造粒機}

これには Briquetting 型と称するロールプレスがあ る。これは一対の型つきロールを回してそのロールの間 で压㩁するもので, カーボン粉末をはじめ, 粘土, 金属

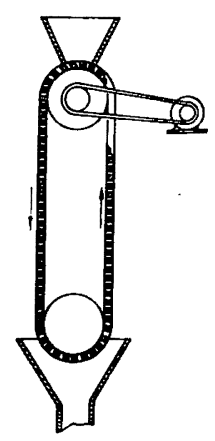

因 5
粉末などの棒状体または球状体の成 型に利用されている。公告されてい るものには，供給機構に特徵のある るの ${ }^{11)}$ ，脱気機粠に特徴のあるる

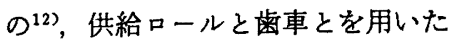
变形 ${ }^{13}$, 外周面に回転方向に断面半 円径の瑇を多数連続して切削した 2 本のロールを用い棒状カーボンを切 断球状化するすの ${ }^{14,15) な と ゙ か ゙ あ る 。 ~}$

さらに変った型式のものとして,

図 5 に示すよ 5 に，多数の小室を設 けた弾性体に張力を加えて小室を搪開させ，これに可団 塊性粉末を装入し，ついで弾性体をすとの状態にすどし て小室を収縮させ，弾性により圧縮し粒状成型した後， 上記弾性体を再び開いて取り出すようにしたるのるあ

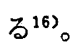

その他 Sugar cubing press や, Chilsonator (Fitz 社）とよばれるものも圧縮成型型である。

\section{2. 押出し型造粒機}

粉粒体に結合剂を加え，一定の大きさの網から押し出 するので, 円筒顆粒機, スクリュ一型造粒機などがあ る。

\section{1）円筒顆 粒 機}

円筒型の金網の中でこれに接して羽根を回転させ，網 目から捏和物を押し出するので医薬品, 食品工業などで 多く用いられている。

最近のものを示すと，円筒槽の外周に沿ってンング （8）を設け円筒槽の周囲を回転するようにし，翼板の回 転に伴い槽外に押し出されリング上に落ちた小粒を外壁 に設けた開放口より遮断板（11）に導き漏斗（9）内に 移行するようにした図6，図7亿示するの ${ }^{17) の ほ か ， 円 ~}$ 筒の外側に摺動するかきとり翼を設け押し出される細条 体を一定寸法に截切するもの ${ }^{18,199}$ などがある。

\section{2）スクリュー型造粒機}

スクリューで押し出するのである。

とくに興味を引くような改良装置は見当らないが，近 年先端に原料を押し返す逆ねじを設けウォーム軸のねじ 底公配を漸減したもの ${ }^{20)}$ ，送出胴部と造粒部との中間の 胴部内周をラッパロ状に拡大する拡大テーパー部に形成 するとともにとの入口および出口部を狭窄形状とし，主 軸外周の直径をこれに沿う直径增大部としたもの ${ }^{21)}$ ，造 粒部にスクリュー軸に支持されるとともに回転する内接 ローラと, 造粒部外周にやはりスクリニ一軸に軸支され たカッターを備えたるの゙22, 拉よび図8に示すような造 


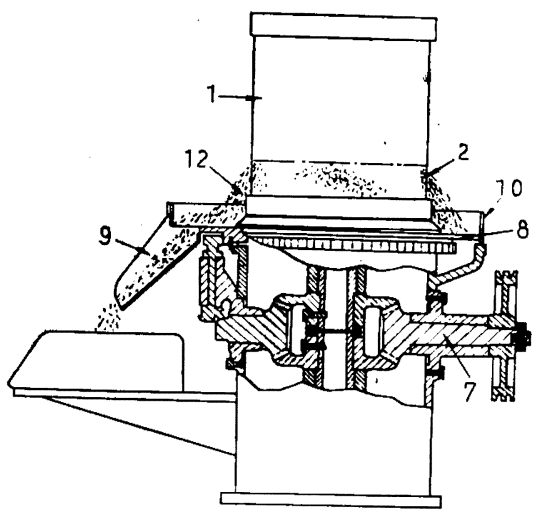

因6（四中番号俚图 7 照)

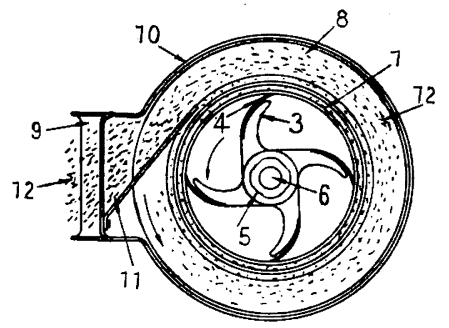

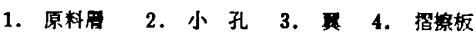

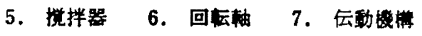

8. リング 9. 流下用佩斗 10 . 外壁

11. 遮板

因 7

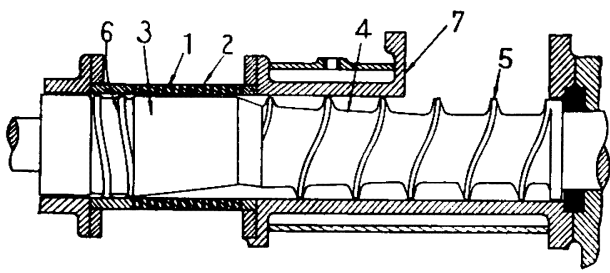

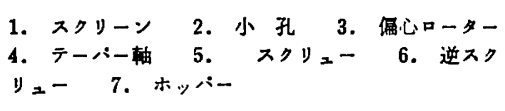
因 8

粒部スクリーン内部に材料圧迫間隙を残した偏心ロータ 一（3）を回転するようにし，孔の穿設軸方向とローター による粉体の押出し方向とのなす角度を可能な限り小さ くしたもの 233などが公告されている。

押出し型造粒機にはその他 Blender Granulator,

Fraser Pin-Granulator とよばれる揘和と造粒を同時 に行ならすのなどがある。なお，合成樹脂の押出し式へ レタイザーは軸周方向でなく前面多孔ダイスから押出し 切断している。

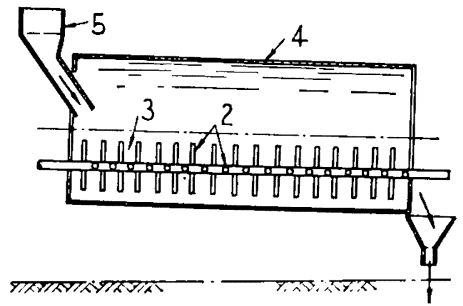

2. 接拌伎杵 3. 擋拌器

4. 回転円筬 5. ホッパー

図 9

\section{3. 枟動型造粒機}

湿った粉体に転動を与えて球形の粒子に凝集あるいは 凝塊させるものである。ドラム型，皿（平鍋）型，振動 型などがあり，セメント，肥料などの工業で広く採用さ れている。

1）トララム型造粒機

水平または少し傾斜を与えた円筒を回転させるもので ある。従来より広く使用されているだけにこの部門の中 では特許の数も一番多いようである。以下その一端につ いて特徴とするところを抽出する。

昭和 31 年公告のものに，粉末装入管と噴霧管をもつ 短円筒状の回転成形機と, 仮成形品を処理する長い截頭 円錐状または円筒状の横型回転整粒機とを同一軸心に据 付け，互に同一か反対方向に回転でさるよ5組合わせ， 両機の周速度を前者は後者より早くさせ，かつ回転成形 機中で給湿と円回転によりあらかじめ形成される成形半 製品をすくいとり，転投手を通して自動的に回転整粒機 に転缎せしめ，半製品を所定の粒度にまでもっていくも のがある24。

またその後，成形ドラムの中でペレットをその入口端 に再循環させ付加した軟毛状物質をペレットに成形する 際の核とするすの ${ }^{25)}$ ，図9に示すような横置回転円筒内 （1）の下方に多数の摚拌枝杵 (2) を設け，円筒の回転と 反対方向に急速回転する擋拌器 (3) を側方に偏持させて 設けたもの 26)などが公告されている。

さらに, 最近のものでは, コッパース社と尼崎製鉄の 一連の機珹がつつけて公報に記載されている。

まず，コッパース社の造粒機から説明すると，図 10〜 12 亿示す装置およびその改良装置で，主要部は，水平 平面上の長さ方向の軸の周りに回転するドラム(10), 原 料供給装置，造粒物取出し装置，ドラムの内面に回転横 軸の方向に間隙をおいて内方に突出している放射状に延 びた環状邪魔板（31），各邪魔板の下向流側上回転軸に 近い部分からドラム排出端の方向への次の邪魔板の上向 


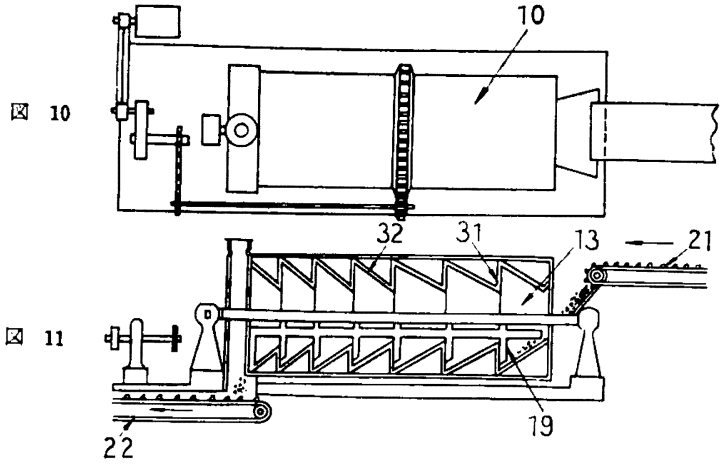

团 12

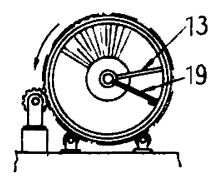
10. 回枟ドラム
13. 掫器
19. 源上器
21. ペルトニンー
22. ベルトコンベ7 31. 門板
32. 球公向板
（各四共通）

流側のその軸からさらに遠い点に 25 50 度のビッチで おのおの傾科して取付けてある環状の転向板（32），材 料をドラム内で落としかつ転ばすための邪魔板間の余積 をかきとるかきとり器（13）とからなるるのおよびその 改良は転向板にかき落とし用刃を設けたるのなどであ $\nwarrow^{27 \sim 29)}$ 。

尼崎製鉄の考案した造粒機は，図13に示すよ5な水 平面より若干傾斜している回転胴（12）の内部に，胴内 壁から離れて落下する完全成鲟粒と不完全成育粒とを分 離し，分離したそれぞれを所望方向に案内するために， 2 枚以上の独立した小板からなる誘導板（20）を設けた bの ${ }^{30,31)}$ ，図 14 に示す，内面に多くの凸凹を設け，材 料粒子のすベりを転がりに変えるよ5にした回転胴に関 するもの ${ }^{311}$ ，傾斜回転胴の内周一部に常にその内周面と 接触または近接するワイヤブラシロールを回転自由に設 けなもの32)，回転胴の出口側に，造粒製品粒をそのまま 流出させないように堰板を設け，この板には，特に前記 回転胴の出口側の粒の分布全域にわたる取出口を穿つと ともに,この取出口には扉板を併設した分粒取出装置に 特徴のあるるの ${ }^{33}$ ，内部に固定した傾斜誘導板を有する 傾斜回転胴を適度の速さで回転しながらこの傾斜誘導板 に強制振動を与えるるの ${ }^{35)}$ か，昭和 36 年から同 38 年に かけて出願公告されている。

このように,この型の造粒機は, 特に回転ドラムの内 部にいろいろな工夫を施こしたるのが多い。

\section{2）皿 (平鍋) 型造粒機}

水平もしくは傾斜した回転血（平鍋）に粉末原料を供 給し造粒するものである。回転ドラム型造粒機同様, 代

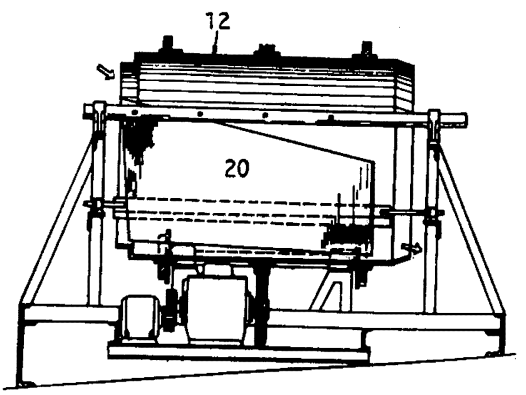

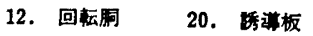
图 13

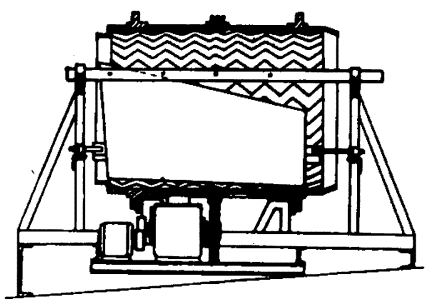

图 14

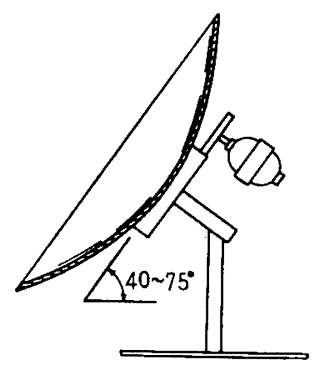

图 15

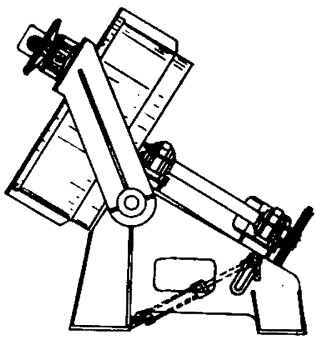

\& 16
表的な転動式造粒機の一種である。

肥料の造粒に厇く採用されているもので, ドイッの エーリッヒ機, ロッシェ造粒機などは有名である。

最近の改良点を特許公報から拾ってみると，球面皿を 用い，表面の大部分を粒形成に利用できるよ5にしたも $の^{362}$ (図 15)，傾斜皿の側面と底面との付着物を除去す るため鋼管内に鎆球を媒体として数個のロッドを往復運 動できるよ5内装し，ロッドに連結した工具を四型回転 体の側，底面に近設した構造の8の ${ }^{37}$ ，图 16 に示す全 装置を油圧機構により駆動し速度と傾斜角とを適宜調節 して希望粒度の粒体を確実に高能率に製造するもの ${ }^{38)}$ どがある。

\section{3） その他の造粒機}

単なる回転ではなく複雑な運動を与えるもので送入原 料は前後左右に振動する骂曲面で造粒されながら，前方 におしあげられ，篩上に落ち，細かいものは次のニニッ 
トにぬけていく振動回転造粒機, 送入原料を偏心回転運 動をする皿上で振動させながら造粒し，大きくなたも のから上に転がってあがり，排出される型式の堅型造粒 機などがある。

以上，粉粒体の凝集力を利用した最近の成型・造粒機 についてその一端を概説したが，䑰面の関係上説明およ び図面を省略したところへ知識の乏しさ，表現のまずさ あ手伝ってわかりにくい単なる紹介だけに終ったようで ある。そして「造粒」は特許の分類上も「13A11」とし

\section{文}

1）垁用新案公報，实公昭 34-13694 号

2）実用新案公報，实公昭 35-23392 号

3）実用新案公報, 实公昭 35-22085 号

4）实用新案公報，実公昭 35-700 号

5）实用新案公報，实公昭 36-17098 号

6）特影公報，特公昭 38-13893 号

7）特部公報, 特公昭 39-638 号

8）特竍公報, 特公昭 35-12796 号

9）特解公報, 特公昭 37-2644 昂

10）特餉公報, 特公昭 37-10343 号

11）特祑公報, 特公昭 34-10776 号

12）特解公報, 特公昭 36-13804 号

13）特敨公報, 特公昭 32-5943 号

14）特部公報, 特公昭 37-1109 号

15）特許公報, 特公昭 32-4860 号

16）特絔公報, 特公昭 37-18883 号

17）实用新案公報，实公昭 36-13797 号

18）实用新案公報，実公昭 36-17097 号

19）特竍公報, 特公昭 37-15239 号

20）实用新案公報，实公昭 37-28079 号

21）特培公報, 特公昭 38-20812 号
て「化学工学」という類で报われているのであるが, 粉 体を用いる备種工業に独特なるのはそれぞれの類で报わ れているものも多く広範に亘るため若下の見落としはあ るかる知れない。

ただ，拙ない本文が，この方面に関心をもたれる方の 調査などの際の一つの参考にであなれば幸いである。

終りに，執筆にあたりいろいろの助言と資料の提供を 賜わった東大・若尾法昭助教授と, 特許庁・萩原亮一審 査官に感謝する。

\section{献}

22）实用新案公報，实公昭 39-3347 号

23）特教公報, 特公昭 39-3262 号

24）特䟽公報, 特公昭 31-7561 号

25）特钽公報，特公昭 32-5554 号

26）实用新案公報，実公昭 33-8747 号

27）特放公報, 特公昭 36-7165 号

28）特新公報, 特公昭 37-3857 号

29）特培公報, 特公昭 37-5153 号

30）特餉公報, 特公昭 36-15184 号

31）特敗公報, 特公昭 36-15185 号

32）特祑公報, 特公昭 36-15186 号

33）特斯公乵, 特公昭 36-15187 号

34）特政公辄, 特公昭 $37-5152$ 号

35）特鼓公報, 特公昭 38-25966 号

36）特新公報, 特公昭 36-6953 号

37）特敗公報, 特公昭 38-2958 号

38）特影公報, 特公昭 38-23924 号

（付施）

なお，図中の番号は原公報記臷のるのをそのまま採用した。

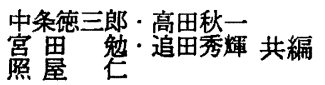

\section{「ユーザーのための送風機と王縮機」}

回転式の送風機と王縮機とについて, 計画, 選定, 運転, 騷音などを親切に詳しく述べてあるのは，さすがに「ユーザ 一のための」と銘を打ったたけのことはある。一方, 空気力 学の基本的な理論や構造についても一通り解説してあるの で，使用者にとっては十分役に立つことと思われる。たた内 容が往復式の压縮機には触れていないが，表題たけ見ると含 まれているように誤解される。はしがをよく読むと回転式の ものだけだと断ってあるが, 表題る「送風機と回転式圧縮 機」とでもしてあれば, 読者になお親切であったろう。 文章むむわかりやすいが久点をいえば著者らが手分けをして それぞれ分担執筆したと見えて少々不ぞろいの点がある。例
オーム社刊，本文 348 ページ 定価 1,400 円

えば㚐考文献の取上げ方も各章によってまちまちで，特に基 礎理論のところでは引用の実験式などに文献を示してもらい たいものがあるのに，この章には全然参考文献があげてない。 その他の章もあったり無かったりである。さらに湿り空気の 説明のところで，「乾き空気 $1 \mathrm{~kg}$ につき」あるいは「湿り空 気 $(1+x) \mathrm{kg}$ につきとすへところを「湿り空気 $1 \mathrm{~kg}$ に つき」としているのは誤りである。

要するに回転式の送風機と圧縮機とを使う立場から根本的 な知識を得よらとする人にはまことに適当で他に類の無い書 物といえよう。

[河 東] 